

\title{
Harmonization of Competition Law: Research on the Transplantability of EU's Law Into ASEAN
}

\author{
Reni Budi Setianingrum and M.Hawin \\ renibs99@gmail.com \\ Universitas Gadjah Mada
}

\begin{abstract}
ASEAN has agreed to run a single market through the ASEAN Economic Community (AEC). The consequence of this free flow of goods and services is the emergence of new business competition, new relevant markets, and potential contact amongst business actors of ASEAN members, and it is possible to create unfair business competition. The implementation of the AEC also has consequences in the field of regulation, specifically the need for harmonization of regulations on competition law in ASEAN members to overcome the problems of cross-border transactions and the absence of competition law in several ASEAN members. This study uses a normative juridical method and aims to examine the harmonization of competition law, research on the transplantability of EU's law into ASEAN. The results of this research show that ASEAN can only adopt the European Union's supranationalism system only for cases of violations of cross border competition law. In contrast, for cases of violations of national competition laws, each country is given sovereignty to apply its own law. This is because the economic characteristics and legal characteristics of business competition vary between ASEAN member countries.
\end{abstract}

Keywords: Harmonization; Competition Law; Supranationalism; Transplantability; ASEAN.

\section{Introduction}

ASEAN is an organization of Southeast Asian Nations that aims to rally cooperation among member countries in order to accelerate economic growth, promote regional peace and stability, and establish cooperation in various fields of mutual interest, which then develops goals for establishing fellowship and cooperation in creating a safe, peaceful and prosperous region. ${ }^{1}$

1 Kementerian Luar Negeri Republik Indonesia, 'Sejarah Dan Latar Pembentukan Asean' (Kementrian Luar Negeri Republik Indonesia, 2015) < https://kemlu.go.id/portal/id/read/980/view/ sejarah-dan-latar-pembentukan-asean>accessed 24 Januari 2020.; Udin Silalahi and Dian Parluhutan, 'The Necessity of ASEAN Competition Law: Rethinking' (2017) 3 Hasanuddin Law Review. 
ASEAN agreed to form an integrated region and to realize these expectations, ASEAN agreed to the establishment of the ASEAN Economic Community (AEC), through the Declaration on the AEC Blueprint (Singapore in November 2007), ASEAN agreed to a joint statement that ASEAN became a single market and production base, a highly competitive economic region, a region of equitable economic development, and a region fully integrated into the global economy. ${ }^{2}$

The provisions of Article 1, number 5 of the ASEAN Charter does not only regulate the ASEAN single market but also regulate the culture of competition. That can be seen from the words "... very competitive and economically integrated with ..." ${ }^{3}$ The word "very competitive" emphasizes that in the ASEAN single market a competitive culture must be created, which has been reflected in the behavior of businesses in conducting their business in their respective countries, because business actors have a goal of becoming bigger than their competitors, both in the domestic market and in the ASEAN regional market. ${ }^{4}$

From the perspective of competition, the consequence of the free flow of goods and services is the emergence of new competition, new relevant markets, and the potential for business actors to be in contact with the competition laws of other ASEAN members. ${ }^{5}$ This has consequences in the field of regulation, namely the need for harmonization of rules on competition law in ASEAN members to overcome the problems of cross-border transactions and the absence of business competition law in several ASEAN members.

Lim Chong Kin, a Singaporean economist, pointed out that there was inconsistency in competition law in ASEAN. ${ }^{6}$ Differences in parameters in the

\footnotetext{
2 ASEAN Economic Community Blueprint.[6].

3 Article 1 Number 5 ASEAN Charter.

4 Udin Silalahi, 'Accelerating the Development of ASEAN Competition Culture' (2012) 12 Law Review.[241].

5 KPPU, Menuju Pasar Bebas Asean (Kompetisi Edisi 2013).[6].

6 Komisi Pengawas Persaingan Usaha, 'Comparisons Of Competition Regimes In Asean' (KPPU 2011)<http://www.kppu.go.id/id/blog/2011/11/Comparisons-Of-Competition-Regimes-InAsean/>. accessed 24 September 2019.
} 
competition law of each country will also trigger potential conflicts if they provide sanctions for business actors domiciled in other countries.

Currently, ASEAN has the ASEAN Regional Guidelines on Competition Policy (ARGCP), this policy has received criticism from competition law experts because the ARGCP is not intended to be a complete law or binding policy instrument for the enforcement of ASEAN member competition, but only serves as a general guide framework for. In other words, the ARGCP only functions as "soft law," not "hard law" about competition rules in ASEAN. ${ }^{7}$

In the absence of regional competition policy, the question is whether ASEAN can implement effective competition law enforcement in building a single ASEAN market without having a regional enforcement agency? The option that can be taken is to harmonize national competition law. Another option is to take inspiration from other regional integration systems such as the European Union to develop a more integrated and supranational competition law system. ${ }^{8}$

This paper seeks to analyze the business competition law enforcement in ASEAN member countries by conducting research on supranational business competition law enforcement in the European Union, then it is concluded that there is a need for harmonization or should an integrated and supranational regulation be formed in ASEAN.

\section{Harmonization of Law}

The diversity of laws is a barrier to trade between countries. Engaging in cooperation agreements with business actors subject to other legal systems will raise questions about which laws will govern the relationship, with the consequence that for one party, the agreement will be subject to unknown rules. It must be taken into account that the law is a reflection of society, and therefore it must also be

\footnotetext{
7 Udin Silalahi and Dian Parluhutan (n 3).[220].

8 Josef Drexl, The Transplantability Of the EU's Competition Law Framework into The ASEAN Region". on Burton Ong (Ed). The Regionalisation of Competition Law and Policy within the ASEAN Economic Community (Cambridge University Press 2018).[213].
} 
considered that juridical fragmentation reflects differences between communities. ${ }^{9}$

The term harmonization comes from the Greek word "harmonia" which means that it is bound harmoniously and accordingly. In the philosophical sense, it means "cooperation between various factors in such a way that these factors produce sublime unity." The term harmonization is etymologically derived from the basic word of harmony, referring to the process that originated from an attempt towards or realizing the harmony system. The term harmony is also interpreted as harmony, compatibility, pleasant balance, and in the sense of psychology, understood as the balance and suitability of aspects of nature, feelings, and others. ${ }^{10}$

Harmonization has been defined as a process to achieve conformity of practice by reducing differences to reach a level of similarity between legal systems but also taking into account that some differences may remain. ${ }^{11}$ In a globalized world and with the rapid development of international trade and commercial transactions, it is necessary to find a general framework ${ }^{12}$ that regulates possible outcomes and reduces the level of uncertainty.

Harmonization of law is a process that harmonizes the legal rules both within the federal framework (which is in the presence of a superior rule-making entity with regard to federation entities), through the adoption of regulatory models agreed at the multilateral level (such as conventions adopted in the OECD or the United Nations) or through a unilateral adoption of the legal system of a foreign sovereign state by a different sovereign state. ${ }^{13}$ Harmonization can also be interpreted as uniting or harmonizing laws in various countries, replacing, at some level, existing

\footnotetext{
9 Stefano Porcelli and Yuanjian Zhai, 'The Challenge for the Harmonization of Law' (2010) 17 Transition Studies Review.[430].

10 Syprianus Aristeus, 'Transplantasi Hukum Bisnis Di Era Globalisasi Tantangan Bagi Indonesia' (2018) 18 Jurnal Penelitian Hukum De Jure.[516].

${ }^{11}$ Catriona Paisey and Nicholas J. Paisey, 'Harmonisation Of Company Law; Lessons From Scottish and English Legal History’ (2010) 42 Management Decision.[1037].

${ }^{12}$ Stefano Porcelli and Yuanjian Zhai (n 9).

13 Enrico Baffi and Paolo Santella, 'The Economics of Legal Harmonization' (Legal harmonization, 2011) < https://www.researchgate.net/publication/290091184_Legal_harmonization> accessed 24 Januari 2020 .
} 
national laws with general rules. ${ }^{14}$ Harmonization of law is developed in the science of law, which is used to show that in the world of law, government policy, and the relationship between the two induces diversity, which can lead to disharmony. ${ }^{15}$ Harmonization of the law has been recognized as a critical element in the form of a modern system. ${ }^{16}$

Many efforts have been made to achieve unification or harmonization, laws in various parts of the world, initiated, among others by European Union authorities, by institutions such as the United Nations Commission on International Trade Law (UNCITRAL), the Organization pour l'Harmonisation en Afrique $d u$ Droit des Affaires (OHADA)/Organization for the Harmonization of Corporate Law in Africa),${ }^{17}$ and the International Institute for the Unification of Private Law (UNIDROIT). In 1926, UNIDROIT created a way to harmonize and coordinate the provisions of civil law from its member countries and promote the acceptance of a 'uniform' legal system. ${ }^{18}$

The notion of harmonization, feasibility, and application has been long discussed throughout the world. In 1994, several African countries encouraged several financial institutions to propose harmonization of commercial law to make trade more competitive and to attract foreign investment. ${ }^{19}$ Another example of international harmonization is the agreement between Australia and New Zealand in the commercial field, such as Intellectual Property Law, Consumer Protection, and Restrictive Trade Practice Law. ${ }^{20}$ In Latin America, harmonization was marked by the birth of MERCOSUR, ${ }^{21}$ where several Latin American countries have

\footnotetext{
${ }^{14}$ Marcel Fontaine, 'Law Harmonization and Local Specificities A Case Study: Ohada and the Law of Contracts' (2013) 18 Uniform Law Review.[50].

${ }^{15}$ Syprianus Aristeus (n 10).

${ }^{16}$ Camilla Baasch Andersen, [et., al.], Towards a Theory of Harmonisation (Theory and Practice of Harmonisation 2011).[573].

${ }^{17}$ Marcel Fontaine (n 14).

18 Syprianus Aristeus (n 10).

19 Aboubacar Fall, 'Harmonisation Of Commercial Law In The Franc Zone (Africa)' (1995) 23 International Business Lawyer.[82].

${ }^{20}$ John H Farrar, 'Harmonisation Of Business Law Between Australia And New Zealand' (1989) 19 Victoria University of Wellington Law Review.[438].

${ }^{21}$ Mercosur, 'Países del MERCOSUR' (Mercosur) < https://www.mercosur.int/quienes-somos/paises-del-mercosur/ >accessed 24 Januari 2020.
} 
begun harmonization of commercial laws. ${ }^{22}$ These countries have similar cultural and legal backgrounds that have created a natural need for harmonization, ${ }^{23}$ and MERCOSUR has achieved several objectives with regional integration that enable them to be more competitive, impose trade restrictions, immigration and help maintain economic balance in the area.

Harmonization of Law not only consists of harmonization of the level of the federation but also harmonization of sovereign states. Unilateral adoption by a sovereign state from the legal system of another sovereign state is defined as a "legal transplant." Legal transplants reduce or potentially eliminate differences between legal systems through the non-cooperative efforts of a unilateral system. ${ }^{24}$ The law of a legal system can be transplanted to another legal system. ${ }^{25}$ The process of accepting foreign legal institutions into the legal system of a country by Watson is called a legal transplant, which is defined as the transfer of a rule or legal system or part of the legal system from one country to another, or from one nation to another. ${ }^{26}$

In the context of law, transplantation means the transplanting of laws from one country to another that has different social realities and legal systems. Frederick Schauer gives the meaning of legal transplantation as "... the process by which laws and legal institutions developed in one country are then adopted by another", ${ }^{27}$ Legal transplantation is not only the process of adopting law as a written rule but also the adoption of the following legal institutions. ${ }^{28}$ Previously this was done by the colonials to their colonies or by countries that had a strong influence on their subordinate states, which came to be known as "concordance".

${ }^{22}$ Gabriel Orozco Restrepo, [et.,al.] , 'Proyeccion Internacional Y Estabilidad Regional: El Caso De Brasil Y El Mercosur En La Politica Internacional. (Articulo De Investigacion)’ 18 Investigacion Y Desarrollo.[242].

${ }_{23}$ Silvia Fazio, The Harmonization of International Commercial Law (Kluwer Law International 2007).[87].

${ }^{24}$ Enrico Baffi and Paolo Santella (n 13).

${ }^{25}$ Syprianus Aristeus (n 10).[514].

26 ibid.

${ }^{27}$ Frederick Schauer, The Politics and Incentives of Legal Transplantations (CID (Center for International Development at Harvard University) Working Paper No 44 2000).

${ }^{28}$ A. Zuhdi Muhdlor, 'Kajian Politik Hukum Te rhadap Transplantasi Hukum Di Era Global' (2016) 5 Jurnal Hukum Dan Peradilan.[197]. 
The term concordance is also a form of passing or taking over or imitating a rule or sub-system of law that applies in one country to another with adjustments as needed. For example, concordance BW Netherlands to be enforced in Indonesia. Because among the various terms, there are basically no differences in understanding, then in this paper, one term will be chosen, which is considered popularly used in the field of law, namely the adoption of the law. ${ }^{29}$

\section{Enforcement of Competition Law in European Union And ASEAN}

For centuries, Europe has been a history of war and peace, where countries try to dominate each other. In its historical context, European integration must be understood as an attempt primarily motivated by the desire to secure peace and stability through establishing appropriate institutions. ${ }^{30}$

The formation of the European Coal and Steel Community (ECSC) in 1951, followed by the formation of two further organizations, the European Economic Community (EEC) and the European Atomic Energy Community (European Atomic Energy Community/ EURATOM). Until today the process of European integration has been characterized by a constant tension between the maintenance of individual Member State power and further integration, which leads to closer unity among European societies, as promised in the opening line of the 1957 Treaty of Rome. ${ }^{31}$

Technically, the EU competition policy covers what is known in many countries as cartel law or, in the United States, 'anti-trust law.' The latter term was adopted because at the end of the nineteenth century, when anti-trust laws were 'invented,' most American cartels were established in the form of trusts. EU competition law rests on three cartel bans contained in Article 101 Treaty on the Functioning of the European Union/TFEU, prohibitions on market abuse in Article

${ }^{29}$ Sundari E, Perbandingan Hukum Dan Fenomena Adopsi Hukum (Cahaya Atma Pustaka 2017).[27].

30 August Reinisch, Essentials of EU Law (Cambridge University Press 2012).[1].

31 ibid. 
102 TFEU, and merger control laws. The three branches of EU competition law are handled by Directorate General IV, now called Directorate General Competition. ${ }^{32}$

Substantive regulations on EU competition law are contained in Articles 101 and 102 of the Treaty on the Functioning of the European Union (TFEU), which prohibit anti-competitive behavior in the European Union, which impacts on trade between EU member states. The European Commission uses the powers granted to it under Regulation 1/2003 (Reg. 1) to enforce EU competition law throughout the European Union, but post-Regulation 1/2003, the substantive rules of the European Union are also applied by the competition authorities of member countries (National Competition Authorities/NCA) as part of the European Competition Network (ECN). Thus, under this decentralized model, the NCA must apply the same substantive competition law rules uniformly in accordance with their previous interpretations by the European Court. ${ }^{33}$

NCAs are required by European Union law to ensure uniform substantive interpretation and application of EU rules by following the European Court's previous decisions, and this is reinforced by Article 16 Reg. 1 which requires the NCA to avoid making decisions that might conflict with previous decisions or anticipated by the European Commission. ${ }^{34}$

As such, it is clear that competition law in the European Union is supranational. The term 'supranational' is usually used to refer to authority over a number of countries. Without entering into a debate about what the state really is, it is enough here to refer to an entity consisting of political authority that uses sovereign authority over an area and the population that lives there. ${ }^{35}$ This term is used to refer to international organizations where some devolution of competencies has occurred

\footnotetext{
32 ibid.

${ }^{33}$ Barry J. Rodger and Mary Catherine Lucey, Convergence and Divergence Within the EU's Supranational Competition Law Framework Norms, Enforcement Rules and Prioritisation in the United Kingdom and Ireland." In Burton Ong (Ed) (The Regionalisation of Competition Law and Policy Within the Asean Economic Community 2018).[236].

34 ibid.

35 Virginie Mamadouh, Supranationalism In The European Union: What About Multilingualism? (Presented At The World Political Map Conference On Nationalisms And Identities In A Globalized World, Maynooth, Belfast 2018).[9].
} 
from member countries to supranational authorities. It is also used to describe the decision-making procedures in an organization: opposing 'supranational' to 'intergovernmental procedures.' When decision making is intergovernmental, each member country can veto an agreement, while supranational decisions are binding on the member states. Hence the supranational nature varies with the specific rules used: from decision making between representatives of the governments of member countries (as long as no consensus is needed) to decision making by universities, councils, or autonomous assemblies. ${ }^{36}$

What about the application of business competition law between ASEAN countries themselves? In the beginning, only four countries in ASEAN adopted the competition law ${ }^{37}$ and currently, nine ASEAN members has already enacted competition law, ${ }^{38}$ except the Cambodian government who will soon finalize a draft law on antitrust and competition and submit it to the National Assembly for approval..$^{39}$

Singapore is an ASEAN member country that has created a climate for attracting investment by liberalizing and deregulating its economy long before its ASEAN neighbors. Singapore steps followed by Malaysia, Thailand, Indonesia, and the Philippines and Vietnam with the Doi Moi program in 1988. Other ASEAN members (besides Brunei Darussalam), namely Laos, Cambodia, and Myanmar, are still impoverished and beginner countries in the process of economic development. ${ }^{40}$

All competition laws in ASEAN countries include provisions to prevent abuse of market dominance and cartels and to provide oversight or control of the merger process. ${ }^{41}$ However, in general, there are two different groups in ASEAN

36 ibid.

37 G. Sivalingam, 'Competition Policy and Law in ASEAN' (2006) 52 The Singapore Economic Review. [242].

38 AEGC, 'ASEAN Experts Group on Competition (AEGC)'(AEGC) <https://aseancompetition.org/aegc $>$ accessed 5 May 2020.

39 Competition Policy International, 'Cambodia To Finalize Antitrust, Competition Draft Law’ (CPI,2020) <https://www.competitionpolicyinternational.com/cambodia-to-finalize-antitrustcompetition-draft-law/> accessed 5 May 2020.

${ }^{40}$ G. Sivalingam (n 37).

${ }^{41}$ Devi Lucy Y. Siadari and Koki Arai, 'International Enforcement of ASEAN Competition Law’ (2018) 9 Journal of European Competition Law \& Practice.[328]. 
competition law. The first group is countries with a recent history of competition law enforcement (Brunei Darussalam, Myanmar, Laos, Cambodia, and the Philippines), and the second group consists of countries with a long history of competition law enforcement (Indonesia, Malaysia, Singapore, Thailand, and Vietnam).$^{42}$

In 2007, the ASEAN Economic Ministers endorsed the formation of the ASEAN Experts Group on Competition (AEGC), which has facilitated workshops, training, and seminars to strengthen the capacity of business competition authorities. ${ }^{43}$ The table below shows the business competition regulations that apply in ASEAN countries: ${ }^{44}$

\begin{tabular}{|c|c|c|}
\hline Nation & Competition law & Authority \\
\hline Brunei Darussalam & Competition Order 2015 & Competition Commission of Brunei Darussalam \\
\hline Cambodia & Draft Competition Law 2016 & Department of Legal Affairs, Ministry of Commerce \\
\hline Indonesia & Law No. 5 Year 1999 & Commission for the Supervision of Business Competition (KPPU) \\
\hline Lao PDR & Competition Law 2016 & Department of Domestic Trade, Ministry of Industry and Commerce \\
\hline Malaysia & Competition Act 2010 & Malaysian Competition Commission (MyCC) \\
\hline Myanmar & $\begin{array}{l}\text { Law No. } 9 \text { Year } 2015 \\
\text { (Pyidaungsu Hluttaw Law No. 9) }\end{array}$ & Department of Trade, Ministry of Commerce (MoC) \\
\hline Philippines & Competition Act 2015 & Philippine Competition Commission (PCC) \\
\hline Singapore & Competition Act 2004 & Competition Commission of Singapore (CCS) \\
\hline Thailand & Trade Competition Act 1999 & $\begin{array}{l}\text { Office of Trade Competition Commission (OTCC), Department } \\
\text { of Internal Trade, Ministry of Commerce }\end{array}$ \\
\hline Vietnam & $\begin{array}{l}\text { Competition Law } \\
\text { (No. 27/2004/QH11) }\end{array}$ & Vietnam Competition Authority (VCA) \\
\hline
\end{tabular}

Source: AEGC 10 website: www.asean-competition.org (2017).

The contents of the substantive provisions of competition law in ASEAN are similar to developed countries, such as the United States, the European Union, and Japan. Jurisdictions on the enforcement of competition law have also long been considered to exceed territorial boundaries because of the following matters, (i)

42 ibid.
43 ibid.

${ }^{44}$ AEGC, 'Competition Policy in ASEAN'(AEGC)<https://asean-competition.org/, https:// asean-competition.org/file/pdf_file/Competition\%20Order\%202015.pdf; https://asean-competition. org/file/pdf_file/Vietnam_Competition\%20Law\%20(2004).pdf; https://asean-competition.org/file/ pdf_file/Thailand\%20Trade\%20Competition\%20Act\%202017.pdf, https://asean-competition.org/ file/pdf_file/Competition\%20Act.pdf; https://asean-competition.org/file/pdf_file/Philippines_Competition\%20Law\%20(2015).pdf; https://asean-competition.org/file/pdf_file/Myanmar-Competition\%20Law\%20(English\%20Version).pdf;https://asean-competition.org/file/pdf_file/CA2010.pdf; https://asean-competition.org/file/pdf_file/Lao\%20PDR\%20Competition\%20Law.pdf; https://asean-competition.org/file/pdf_file/law_5_year_1999_.pdf; https://asean-competition.org/file/pdf_file/ Draft\%20Law\%20on\%20Competition\%202018.pdf $>$ accessed 5 May 2020. 
the doctrinal effect that domestic competition law can be applied if the influence of foreign cartels affects their markets, (ii) objective territorial principles where domestic law applies to action completed within the country, or (iii) think that execution will be extended to direct, substantial and predictable actions. That is, for the enforcement of the domestic cartel case, the law of domestic competition can be applied, whether it is agreed abroad or not. In general, the competition laws of ASEAN countries are also based on the idea of this law enforcement jurisdiction. However, at present, the jurisdiction of each country's competition law enforcement is one of the essential problems in handling real cases by practitioners. ${ }^{45}$

In principle, each state jurisdiction covers any business activity in a country territory and can be extended to certain international transactions. The legal jurisdiction of each competition law determines the general power of the competition authority to exercise control over all persons and matters within their territory and related international transactions.

There are several classifications of the characteristics of each country's supervision of the foreign business. State competition laws can be applied to foreign companies in Brunei Darussalam (Part 34), Cambodia (Article 3), Malaysia (Part 3), Philippines (Part 3), Singapore (Part 33), and Thailand (Part 4) also apply similar provisions. Indonesian competition law can be applied to foreign companies that carry out activities within the jurisdiction of the Republic of Indonesia (Article 1 (5)). Laos competition law can be applied to foreign companies with a business presence in Laos (Article 4). Vietnamese competition law can be applied to foreign companies operating in Vietnam (Article 2). Myanmar does not have any specific provisions regarding this matter.

According to this provision, the investigation in each country, in general, can be extended to foreign business actors conducting business in ASEAN. Questions about jurisdictional and substantive issues in competition policy are, in some respects, modernized ASEAN competition law. In this case, experts have noted

${ }^{45}$ Devi Lucy Y. Siadari (n 41).[331]. 
several issues that must be dealt with by the competition authorities in ASEAN, which are shown in the table below. ${ }^{46}$

\begin{tabular}{|c|c|c|}
\hline Nation & Jurisdiction & Article \\
\hline Brunei Darussalam & $\begin{array}{l}\text { Agreements and undertakings that abuse the dominant position, and anticipated } \\
\text { mergers or mergers that take place outside of Brunei Darussalam. }\end{array}$ & $\operatorname{Sec} 10(1)$ \\
\hline Cambodia & $\begin{array}{l}\text { All actions (inside or outside the territory of the Kingdom of Cambodia) that may cause } \\
\text { competitive harm to the Cambodian economy are prohibited by this law; } \\
\text { All persons to the extent that they conduct business. }\end{array}$ & Art.3 \\
\hline Indonesia & Domestic businesses or those that operate within the jurisdiction of the Republic of Indonesia. & Art.1(5) \\
\hline Lao PDR & $\begin{array}{l}\text { The sale of goods and services in business activities: domestic and foreign individuals, } \\
\text { legal entities, and organisations with a business presence in Lao PDR, including state- } \\
\text { owned enterprises (SOEs). }\end{array}$ & Art.4 \\
\hline Malaysia & $\begin{array}{l}\text { Any commercial activity within and outside Malaysia that affects competition in any } \\
\text { market in Malaysia. }\end{array}$ & Sec.3 \\
\hline Myanmar & No explicit guidance on its geographic jurisdiction. & - \\
\hline Philippines & $\begin{array}{l}\text { Any person or entity engaged in any trade, industry, or commerce in the Republic of the } \\
\text { Philippines. } \\
\text { International trade in and/or outside the Philippines that affects trade, industry, or } \\
\text { commerce in the Republic of the Philippines. }\end{array}$ & Sec. 3 \\
\hline Singapore & $\begin{array}{l}\text { Agreements or undertakings that abuse the dominant position, and anticipated mergers } \\
\text { or mergers that take place outside Singapore. } \\
\text { Any party, or any matter, practice, or action that arises from an agreement, such as a } \\
\text { dominant position, anticipated mergers or mergers that take place outside Singapore. }\end{array}$ & Sec. 33 \\
\hline Thailand & $\begin{array}{l}\text { Other than the government, state enterprises under the law on budgetary procedure, } \\
\text { farmers' groups, co-operatives, or co-operative societies recognised by laws and intended to } \\
\text { benefit of the occupation of farmers and businesses prescribed by ministerial regulations. }\end{array}$ & Sec. 4 \\
\hline Vietnam & $\begin{array}{l}\text { Organisations and individuals conducting business in Vietnam. } \\
\text { Industry associations operating in Vietnam. }\end{array}$ & Art. 2 \\
\hline
\end{tabular}

From this table, it can be concluded that cooperation is a significant challenge facing competition law and law enforcement in ASEAN. The question is, what competition law will be applied to protect and maintain fair competition among ASEAN member countries? And who can apply the law? Until now, there is no ASEAN Competition Law to enforce fair competition if there are business actors who violate competition law in all ASEAN jurisdictions. So now is the time to rethink the need for ASEAN Competition law, can EU supranationalism be applied to the competition law of ASEAN member countries?.

\section{Transplantation of EU's Supranationalism in ASEAN Competition Law}

The European Union is a reference point for other regional organizations throughout the world and has the most advanced and most experienced regional

\footnotetext{
${ }^{46}$ AEGC (n 38).
} 
competition laws in the world. Even the European Union has even taken a proactive role. In bilateral agreements with Caribbean countries and Central American countries, the European Union has included obligations on these countries to create regional competition laws and competition authorities.

ASEAN has chosen to take a soft legal approach to its regional competition policy. ASEAN member countries pay close attention not only to national sovereignty as a consequence of their colonial past and their ethnic, religious, and cultural diversity but also to the vast differences from the current domestic political and economic system. Therefore, ASEAN prefers convergence of national law over supranational law and cooperation on centralized enforcement. ${ }^{47}$

The ASEAN regional guidelines on competition policy (ASEAN Regional Guidelines on Competition Policy/ARGCP), only mandate the establishment of a regional cooperation platform between the Competition Authority (CA) in ASEAN, whose functions are: exchanging experiences, identifying best practices, trying implementing cooperative competition policies and legislative harmonization. However, this regional platform cannot carry out the rulemaking function and work based on consensus building. Thus, each time the regional platform will reach consensus on recommendations or "best practices," each CA from ASEAN countries can decide whether and how to implement recommendations by means of unilateral, bilateral, or multilateral arrangements. ${ }^{48}$ Admittedly, the reason behind this consensus-making approach is the "conflict of interest" between competition law and other national economic goals of ASEAN countries. ${ }^{49}$

In order to enhance ASEAN's competitiveness, not least in terms of regional attractiveness for foreign direct investment, a more integrated competition law

\footnotetext{
47 Josef Drexl (n 8).

48 Huong L. Ly, 'Regional Harmonization of Competition Law and Policy: An ASEAN Approach’ (2012) 2 Asian Journal of International Law 291.[310].

49 D.P. Wood, The Impossible Dream: Real International Antitrust (University of Chicago Law School Chicago Unbound 1992).[307].
} 
system may be needed..$^{50}$ The motivation to develop an ASEAN competition regime can be categorized into two main factors, ${ }^{51}$ first, regional obligations where ASEAN members have committed to completing their overall commitment to shaping the AEC. Second, economic pressure, where ASEAN members have recognized that competition policy can be a tool to promote integration and regional market competitiveness in facing competition challenges from China and India. The question remains whether ASEAN can implement effective competition law enforcement to promote its economic goals in building a single ASEAN market without the existence of a regional enforcement body. ${ }^{52}$

There are several options, including taking inspiration from other regional integration systems, one of which is the EU competition law, in particular, to develop a more integrated and supranational competition law system. Discussion on whether EU competition law can be used as a guide, role model, or even a template for ASEAN competition law in the future is a topic that has long been discussed. This idea was also addressed by the European Union itself when the European Union Center in Singapore recently published a "working paper" on whether EU competition law can be used as a template for ASEAN. ${ }^{53}$

There are three main arguments in support of the creation of supranational ASEAN competition law, namely: ${ }^{54}$

1. The first argument relates to the goal of creating a single market in the ASEAN region. In the EU, the main reason for competition law lies in the aim of ensuring the functioning of the internal market. EU competition law aims to prevent efforts from separating internal markets through anti-competitive means.

2. The second argument, supranational law works better to create an equal market

\footnotetext{
${ }^{50}$ ibid.

51 Wan Khatina Nawawi, Regionalisation of Competition Law and Policy in ASEAN Why, How and When?" In Burton Ong (Ed) (The Regionalisation of Competition Law and Policy Within the Asean Economic Community 2018).[31].

52 Damien Geradin, 'Competition Law and Regional Economic Integration: An Analysis of the Southern Mediterranean Countries' (World Bank 2004) Working Paper 35.

${ }^{53}$ Barbora Valockova, 'EU Competition Law: A Roadmap For ASEAN' (2015).[9].

54 Josef Drexl (n 8).[227-228].
} 
for all businesses compared to the national legal network. The same rules will apply to all companies doing business in the region and in any member country.

3. Third, supranational law can help 'rent-seeking' from domestic companies vis a vis/face to face with national authorities and national legislatures. Such rentseeking can be very successful in cases where companies argue that certain special privileges under national law will increase their competitiveness internationally. Supranational law, in general, can help limit national industrial policies that damage the level of competition in the region.

There are at least some criteria that a competition authority needs to work across countries, namely: ${ }^{55}$

a. Established and work throughout the member country;

b. Has the same legal base (Competition Law) in all member areas;

c. Has the authority to take legal action in all member countries;

d. Have facilities and human resources that support coordination and work with all relevant institutions in member countries.

Whether, to what extent, and in what way the supranational model of EU competition law can be "transplanted" into the ASEAN region depends on the level of "transplantability" of EU law in the ASEAN context. In this regard, Shahein, explained that there are three different models of legal transplants as applied to competition law seem very useful. ${ }^{56}$

The three models are (1) the cut-and-paste model, ${ }^{57}(2)$ the contextualization $\operatorname{model}^{58}$, and (3) the tailor-made model. ${ }^{59}$ The 'cut and paste' model, where countries "borrow" the overall rules of competition from the Western economy and graft them into their jurisdiction. The 'contextualization' approach, involves the removal of basic concepts and principles from foreign jurisdictions and carefully examining and modifying them to suit the needs of the country. The third

\footnotetext{
${ }^{55}$ Mukti Fajar ND, 'Competition Law in ASEAN: The Future of Competition Authority in ASEAN Economic Community’ (2019) 7 Humanities \& Social Sciences Reviews 247.[251].

${ }^{56}$ H Shahein, Designing Competition Laws in New Jurisdictions: Three Models to Follow, " In Whish, R. And Townley, C. (Eds.). New Competition Jurisdictions: Shaping Policies and Building Institutions (Edward Elgar 2012).[35-66].

${ }^{57}$ Whish, R and Townley (n 56).[45].

58 ibid.[51].

59 ibid.[57].
} 
approach is to adopt specific competition rules to fit their market characteristics ('tailor-made' approach).

Assuming that ASEAN countries are considering adopting competition law and European Union institutional design, two core issues must be discussed. The first is to question what approach they have followed when formulating and drafting their laws. Do they follow the competition model of the United States and / or the European Union so as not to "reinvent the wheel"60 (cut-and-paste model); whether they succeeded in transplanting basic concepts, adjusted to their local needs and their market context (the contextualization model); or do they make a model where their competition laws reflect their market characteristics such as uncertainty, barriers and political control (tailor-made model)?. ${ }^{61}$

In the contextualization model, the characteristics and principles of the provisions of foreign law are adopted blindly, with the awareness that the rules and principles will apply differently in different contexts. This requires certain adjustments to suit different contexts in the country.

Whereas the tailor-made model, which Shahein considers an ongoing step of contextualization, different policy objectives and the specificity of the target country are fully taken into account, which can lead to very different goals and approaches to competition law, despite the core concept of more experienced foreign legal provisions might still be recognizable. The legislature prioritizes sustainable economic development as the ultimate goal of competition law with consumer welfare-oriented. ${ }^{62}$

From a historical point of view, competition law in ASEAN is far different from EU competition law. The basic concepts of regional economic integration, the

${ }^{60}$ Dictionary Cambridge 'To Waste Time Trying to Create Something That Someone Else Has Already Created' (Dictionary Cambridge) $<$ https://dictionary.cambridge.org/dictionary/english/ reinvent-the-wheel $>$. accessed 5 May 2020.

${ }^{61}$ Eleanor M. Fox, 'Economic Development, Poverty and Antitrust: The Other Path' (2007) 13 Southwestern Journal of Law and Trade in the Americas. [113].

${ }^{62}$ Michal Gal and E Fox , 'Drafting Competition Law for Developing Jurisdictions: Learning from Experience," In E Michal Gal, [et.,al.]' The Economic Characteristics of Developing Jurisdictions: Their Implications for Competition Law ( Edward Elg 2015).[296-356]. 
legislative framework, institutional structure, and socio-economic context are very different between the European Union and ASEAN. Therefore, instead of copying from the European Union, ASEAN can learn from the European Union to develop its own approach.

The establishment of the ASEAN competition policy has proved to be very burdensome. At present, in the ASEAN region, as in other jurisdictions, competition policy is recognized as an essential element of regional economic integration. The initial decision to strengthen regional economic cooperation and, ultimately, integration returned to what was called Bali Concord II in 2003. But the text from Bali Concord II did not contain any commitment regarding competition law. The ASEAN Regional Guidelines on Competition Policy was only adopted in 2010. This reflects that ASEAN refrained from going to the supranational system. Guidelines only use soft legal approaches. Because they are not binding, it is very doubtful whether they will indeed enhance the ASEAN integration project.

Regarding the current state of development of regional competition law, the European Union and ASEAN differ in several respects. The most crucial difference is the supranational character of the European Union system, on the one hand, and full respect for national sovereignty among ASEAN member countries in the field of competition law. From the start, EU competition law emerged from treaties as a supranational law that had a direct impact on business actors in the legal systems of member countries.

Countries that join the European Union must accept the unity of EU competition law. Likewise, the European Union imposes its competitive legal concept in a third country that has close relations. In such situations, full integration or harmonization is preferred over a more appropriate contextualization model. However, the regional integration model does not need to require a cut-and-paste model internally. They can also allow contextualization or even 'tailor-made,' which will be explored further below. As we can see, the ASEAN legal system has so far not yet developed rules that will prevent member countries from following the 'tailor-made' model. This also means that competition laws in ASEAN 
countries are very different. ${ }^{63}$

Centralization also characterizes the formation of principles of competition law in the European Union. It is the commission that adopts the block exemption regulations and confirms the policy function further by adopting Guidelines on various aspects of EU competition law. More importantly, EU competition law is interpreted uniformly and applied by the European Court, namely the General Court (GC) and the Court of Justice of the European Union (CJEU). In contrast, there are no such central institutions in the ASEAN region. ASEAN depends exclusively on the convergence and cooperation of national competition institutions.

In short, the design of ASEAN's regional competition policy is, in many ways, different from the supranational system and is more centralized in the European Union. However, it must be noted that EU competition law also provides flexibility to its member states. They are still free to adopt and apply competition law for cases that are outside the realm of European law and, even within the scope of European Union law, for unilateral restraint. In addition, national authorities and courts currently play a far more critical role in the enforcement of EU competition law than in the past

\section{Conclusion}

The analysis above raises the question of whether ASEAN should move from a convergence approach to a European approach to supranational law? ASEAN makes a wise decision by setting a time limit for its member countries to adopt national competition laws. Such an approach has clear benefits because it creates a culture of competition, and member countries have full flexibility in the concrete design of national systems. ASEAN cannot implement supranational law as European Union because ASEAN countries adhere different legal systems.

However, this argument must not exclude the adoption of a supranational competition law whose application is limited to cross-border cases. This such a

\footnotetext{
${ }^{63}$ G. Sivalingam (n 37).
} 
law would enable national institutions to continue their independent work in national cases. The reason for applying supranational law for enforcing crossborder violations and applying national law for national violations is because of the different law system of ASEAN members, which makes it impossible for a supranational authority to handle all cases adequately. Another strategy is to harmonize national competition law to build an equal market in the region.

From the description above, it can be concluded that ASEAN can only adopt the European Union supranationalism system only for cases of violations of competition law across ASEAN member countries. In contrast, for cases of violations of national competition laws, each country is given sovereignty to apply its own national competition law because the economic characteristics and legal characteristics of business competition vary between ASEAN member countries.

\section{Bibliography}

AEGC, 'ASEAN Experts Group on Competition (AEGC)'(AEGC) $<$ https://aseancompetition.org/aegc $>$ accessed 5 May 2020.

AEGC, 'Competition Policy in ASEAN'(AEGC)<https://asean-competition.org/, accessed 5 May 2020.

A. Zuhdi Muhdlor, 'Kajian Politik Hukum Terhadap Transplantasi Hukum Di Era Global' (2016) 5 Jurnal Hukum Dan Peradilan 195.

Aboubacar Fall, 'Harmonisation Of Commercial Law In The Franc Zone (Africa)' (1995) 23 International Business Lawyer.

Article 1 Number 5 ASEAN Charter.

ASEAN Economic Community Blueprint.

August Reinisch, Essentials of EU Law (Cambridge University Press 2012).

Barbora Valockova, 'EU Competition Law: A Roadmap For ASEAN' (2015).

Barry J. Rodger and Mary Catherine Lucey, Convergence and Divergence Within the EU's Supranational Competition Law Framework Norms, Enforcement Rules and Prioritisation in the United Kingdom and Ireland." In Burton Ong (Ed) (The Regionalisation of Competition Law and Policy Within the Asean 
Economic Community 2018).

Camilla Baasch Andersen, [et.,al.], Towards a Theory of Harmonisation (Theory and Practice of Harmonisation 2011).

Catriona Paisey and Nicholas J. Paisey, 'Harmonisation Of Company Law; Lessons From Scottish and English Legal History’ (2010) 42 Management Decision.

Competition Policy International, 'Cambodia To Finalize Antitrust, Competition Draft Law' (CPI,2020) < https://www.competitionpolicyinternational.com/ cambodia-to-finalize-antitrust-competition-draft-law/ $>$. accessed 5 May 2020 .

D.P. Wood, The Impossible Dream: Real International Antitrust (University of Chicago Law School Chicago Unbound 1992).

Damien Geradin, 'Competition Law and Regional Economic Integration: An Analysis of the Southern Mediterranean Countries' (2004) Working Paper 35.

Devi Lucy Y. Siadari and KA, 'International Enforcement of ASEAN Competition Law' (2018) 9 Journal of European Competition Law \& Practice.

Dictionary Cambridge 'To Waste Time Trying to Create Something That Someone Else Has Already Created' (Dictionary Cambridge) <https://dictionary. cambridge.org/dictionary/english/reinvent-the-wheel $>$. accessed 5 May 2020.

Eleanor M. Fox, 'Economic Development, Poverty and Antitrust: The Other Path' (2007) 13 Southwestern Journal of Law and Trade in the Americas.

Enrico Baffi and Paolo Santella, 'The Economics of Legal Harmonization' $<$ https:// www.researchgate.net/Publication/290091184_Legal_Harmonization>.

Frederick Schauer, The Politics and Incentives of Legal Transplantations (CID (Center for International Development at Harvard University) Working Paper No 44 2000).

G. Sivalingam, 'Competition Policy and Law in ASEAN' (2006) 52 The Singapore Economic Review 241.

Gabriel Orozco Restrepo, [et.,al.], 'Proyeccion Internacional Y Estabilidad Regional: El Caso De Brasil Y El Mercosur En La Politica Internacional. (Articulo De Investigacion)' 18 Investigacion Y Desarrollo.

Huong L. Ly, 'Regional Harmonization of Competition Law and Policy: An ASEAN Approach' (2012) 2 Asian Journal of International Law 291. 
John H Farrar, 'Harmonisation Of Business Law Between Australia And New Zealand' (1989) 19 Victoria University of Wellington Law Review.

Josef Drexl, The Transplantability Of the EU's Competition Law Framework into The ASEAN Region". on Burton Ong (Ed). The Regionalisation of Competition Law and Policy within the ASEAN Economic Community (Cambridge University Press 2018).

Kementerian Luar Negeri Republik Indonesia, 'Sejarah Dan Latar Pembentukan Asean' (Kementrian Luar Negeri Republik Indonesia, 2015) <https:// kemlu.go.id/portal/id/read/980/view/sejarah-dan-latar-pembentukan-asean $>$ accessed 24 Januari 2020

Komisi Pengawas Persaingan Usaha, 'Comparisons Of Competition Regimes In Asean' (KPPU 2011)<http://www.kppu.go.id/id/blog/2011/11/ComparisonsOf-Competition-Regimes-In-Asean/>. accessed 24 September 2019.

KPPU, Menuju Pasar Bebas Asean (Kompetisi Edisi 2013).

Marcel Fontaine, 'Law Harmonization and Local Specificities A Case Study: Ohada and the Law of Contracts' (2013) 18 Uniform Law Review 50.

Mercosur, 'Mercosur En Pocas Palabras' <http://www.mercosur.int/T_Generic. Jsp?Contentid $=3862 \&$ Site $=1 \&$ Channel $=$ Secretaria\&Seccion $=2 \#>$.

Michal Gal and E Fox , 'Drafting Competition Law for Developing Jurisdictions: Learning from Experience," In E Michal Gal, [et.,al.]' The Economic Characteristics of Developing Jurisdictions: Their Implications for Competition Law ( Edward Elg 2015).

Michal Gal and Fox E, Michal Gal and Fox E 'Drafting Competition Law for Developing Jurisdictions: Learning from Experience,' In Gal, M. EtAl' (2015) Edward Elg The Economic Characteristics of Developing Jurisdictions: Their Implications for Competition Law.

Mukti Fajar ND, 'Competition Law in ASEAN: The Future of Competition Authority in ASEAN Economic Community' (2019) 7 Humanities \& Social Sciences Reviews 247.

Shahein H, Designing Competition Laws in New Jurisdictions: Three Models to Follow, "In Whish, R. And Townley, C. (Eds.). New Competition Jurisdictions: Shaping Policies and Building Institutions (Edward Elgar 2012).

Silvia Fazio, The Harmonization of International Commercial Law (Kluwer Law International 2007). 
Stefano Porcelli and Yuanjian Zhai, 'The Challenge for the Harmonization of Law' (2010) 17 Transition Studies Review 430.

Sundari E, Perbandingan Hukum Dan Fenomena Adopsi Hukum (Cahaya Atma Pustaka 2017).

Syprianus Aristeus, 'Transplantasi Hukum Bisnis Di Era Globalisasi Tantangan Bagi Indonesia’ (2018) 18 Jurnal Penelitian Hukum De Jure 513.

Udin Silalahi, 'Accelerating the Development of ASEAN Competition Culture' (2012) 12 Law Review 241.

Udin Silalahi and Dian Parluhutan, 'The Necessity of ASEAN Competition Law: Rethinking' (2017) 3 Hasanuddin Law Review 218.

Virginie Mamadouh, Supranationalism In The European Union: What About Multilingualism? (Presented At The World Political Map Conference On Nationalisms And Identities In A Globalized World, Maynooth, Belfast 2018).

Wan Khatina Nawawi, Regionalisation of Competition Law and Policy in ASEAN Why, How and When?" In Burton Ong (Ed) (The Regionalisation of Competition Law and Policy Within the Asean Economic Community 2018).

HOW TO CITE: Reni Budi Setianingrum, 'Harmonization of Competition Law: Research on the Transplantability of EU's Law Into ASEAN' (2020) 35 Yuridika. 